\title{
Anthropology and the study of contradictions
}

\author{
Edited by David BerLINER, Université Libre de \\ Bruxelles
}

David BERLINer, Université Libre de Bruxelles; Michael LAMBEK, University of Toronto, Scarborough; Richard SHweder, University of Chicago; Richard IRvine, University of Cambridge; Albert PietTe, Université Paris-Ouest, Nanterre

Contradictions constitute one fundamental aspect of human life. Humans are steeped in contradictory thoughts, feelings, and attitudes. In this debate, five anthropologists adopt an individual-centered and phenomenological perspective on contradictions. How can one live with them? How to describe them from an anthropological point of view? Should we rethink our dear notion of the "social agent" through that of contradiction?

Keywords: contradictions, anthropological theory, experience, reflexivity, cognitive dissonance

\section{Anthropology as the science of contradictions}

David Berliner

Once during my anthropology of gender class, one student explained to us her embarrassment when, being a convinced feminist, she realized that she was enthusiastically singing the sexist lyrics of a popular track. In the same vein, I often think about environmentalists who are, at the same time, frequent flyers or smokers. Take also anti-capitalist intellectuals who, through their editorial and 
evaluative practices, participate actively in academic capitalism. Critical thinkers, too, are sometimes steeped in contradictions. Passionately defending a cause, they might ignore inconsistencies, much like when you fall in love and lose some discernment. Certainly, these contradictions can also be interpreted as triggers for intellectual creativity. Late in his life, Bourdieu referred to his own "habitus clivé" between his modest social origins and his successful trajectory in the French intellectual aristocracy as a "cleft habitus, generating all sorts of tensions and contradictions” (2004: 111). In his book Le génie du mensonge (2015), François Noudelmann scrutinizes the life of several philosophers, emphasizing the creative contradictions between their concepts and their lives: Jean-Jacques Rousseau wrote L'Emile, his treatise about education, while he was abandoning his five children. At the time she concocted The second sex, Simone de Beauvoir maintained an alienating love relationship with Nelson Algren. And what about Deleuze who approached nomadism better than anyone and yet hated traveling? Needless to say, we could find numerous examples of these contradictory thoughts, feelings, and attitudes in all humans.

Yes, humans are full of contradictions. So, how to live with principles, emotions, and behaviors that contradict each other? How can one have a thought, and in the same movement, its opposite?

Psychoanalysts, following Freud, teach us that it is the very foundation of the unconscious to be animated by opposing forces-for instance, in the idea of the "splitting of the ego" (Freud 1938), according to which a child simultaneously accepts and disavows the reality of castration (Verleugnung). On the other hand, behaviorists, after Festinger (1957), use the concept of "cognitive dissonance" to describe a discomfort resulting from inconsistency between knowledge. Scholars of social representation (such as Serge Moscovici) have coined the notion of "cognitive polyphasia" to describe how different types of knowledge coexist within a single individual, and how thoughts can hold contradictory meanings (Provencher 2011). Among anthropologists, there is ample literature about contradictions existing between different social and cultural groups, but also on contradictions in the Marxist sense of the term. I am not discussing them in this short piece. Instead, I ask: what if one adopts an individual-centered and phenomenological perspective on contradictions? How might we describe them from an anthropological point of view? Should we rethink our dear notion of the "social agent" through that of contradiction?

Early anthropologists were interested in exploring the universality of the "law of non-contradiction," starting with Lévy-Bruhl (1910) and his law of participation according to which, in primitive societies, contradictory statements about reality can coexist. During his work among the Dobuans and the Manus in the 1920s and 30s, Reo Fortune documented several examples of ambivalent explanations, incompatible beliefs, and intrapersonal contradictions, mostly emphasizing how they are expressed through dreams (Lohmann 2009). This avenue for reflection was pursued by Roger Bastide who, in 1955, theorized the "compartmentalization principle" (principe de coupure). In the syncretic Afro-Brazilian rituals he studied, Bastide highlighted the existence of a mechanism allowing "the simultaneity of contradictory behaviors without inner conflict" (1955, my translation). The Candomblé adept, Bastide writes, "does not lie. He is both a Catholic and fetishist. The two things are not opposed but separate" (ibid.). According to him, the 
"compartmentalization principle" overcomes the idea of a split between two or more opposing forces that would fight within the individual. It renders possible the coexistence of contradictions.

To better understand the workings of such a principle, Bastide's observations have to be nuanced. In particular, words and behaviors must be analyzed in context. During the sacrifices described by Evans-Pritchard, the Nuer say that "a cucumber is an ox," but they do not confuse the two in their daily lives. In her study of witchcraft in contemporary England, Tanya Lurhmann has lucidly shown how adepts of Wicca, who are part of a rationalized world, cope with cognitive dissonance. Mostly, they use Bastide's principle to distinguish between domains of truth that "belong to different dimensions" (Lurhmann 1989: 282), and they find ways to defend, philosophically and theologically, their magical practices in the front of sceptics. To borrow a phrasing from Stanley Tambiah, they live in a "world of multiple orderings of reality" (1990: 84).

But such domain-specific approaches should be complexified as well. A religious belief can aggregate a diversity of contradictory thoughts and trigger feelings and actions that contradict each other. The famous formula "Je sais bien, mais quand même ..." discussed by Octave Mannoni (1969) opens a rich field of inquiry about the complexity of belief, also explored by Paul Veyne in Les Grecs ont-ils cru à leurs mythes? (1983). Jean Bazin (2008) has exemplified this brilliantly with the case of Madame de Deffand who says that she does not believe in ghosts, but is afraid of them. "Je ne crois pas dans les fantômes, mais jen ai peur" reveals a weird, contradictory aspect of belief: the elderly French lady doesn't believe, theoretically, in the existence of spirits, but living in an old manor with creaky floors triggers emotional reactions of fear and practical inferences about ghosts. In a different vein, Dennett and LaScola (2010) have conducted in-depth interviews with preachers who claim that they have lost faith in God, but still go on with their pastoral duties.

Religion appears to constitute a site privilégié for the investigation of contradictory statements, feelings, and practices (see also Berliner and Sarro 2007, Schielke and Debevec 2012). And yet, Bruno Latour has shown that scientific practices are full of these mixed entities as well, at once constructed and true, discovered and handmade, with scientists often defying the law of non-contradiction (Latour 1996: 21-22).

Here I want to suggest some more basic ideas about a subject that deserves to be explored further. To begin with, I think that we can use the Marxist notion of contradiction, i.e. "a situation when two seemingly opposed forces are simultaneously present" (Harvey 2014: 1), but in a slightly transformed manner, to observe how these opposed forces may operate on an individual level. The contradictions that interest me in this context concern nonreflexive, i.e unconscious, intrapersonal inadequation between discourses, ideas, feelings, values, and practices. Yet, I already hear the critics: How can anthropologists attest to the existence of inconsistencies in people if they are not conscious of them? How to get access to them if they are intrapersonal? Also, how to distinguish between the involuntarily contradictions of everyday life and the social skills at expressing public views that are opposed to dissimulated private thoughts (thus voluntarily assuming contradictions in different contexts, like politicians often do)? 
I take these questions very seriously, and I'll come back to them in the following paragraphs. But let us first look at some possible combinations. Many individuals live with certain principles and hold attitudes that are opposed to these principles. A colleague condemns ecological disaster caused by carbon emissions and yet keeps flying all the time. Another one denounces the neo-liberalization of universities while participating in a very competitive academic ethos via the economics of citationality and neoliberal evaluation procedures. (I call these academics the "neoliberal revolutionaries.") Some publicly condemn adultery and cheat in secret. Likewise, emotions and thoughts may seem in contradiction, like when Madame de Deffand is scared by spirits, but does not believe in them. It is equally possible to identify contradictions operating between ideas themselves, often contextually. American college students claim that cheating during examinations is wrong, still in many situations they see it as acceptable (see McGabe 1992). In his latest book Ethical life, and building on Jane Hill's ethnography of Mexico, Webb Keane describes the "inner clash of ethical voices" lived by Don Gabriel, an Indian man who, after murdering his son, is trapped between two value systems: the idealized Indian ethical world associated with Mexicano language, and the world of urban capitalism (where Spanish dominates), both involving "serious ethical commitments and the difficulties that their contradictions pose for him" (Keane 2016: 146). Extreme cases in horror: executioners during the day who turn out to be affectionate fathers at night. Can a derivative trader, responsible for increasing global inequality, be a humanist with a big heart during his vacations? And, if so, how to be a "humanist trader"?

Certainly, anthropologists themselves do not escape contradictions. Politically progressive at home, some advocate for the respect of oppressive cultural practices when it comes to their faraway field sites. In the field, the moral sense of the anthropologist may become instable. Suffice it to think of the experience of Kenneth Good (1991), whose participation in the lives of the Yanomami was intense and controversial, when he decided to get married to a fifteen year old girl, Yarima. In the context of Yanomami life, such conduct, morally unacceptable in the United States, proved not only moral but also desirable. While anthropologists are invited to behave ethically in the field (Scheper-Hughes 1995), the chameleon-like experience of participant observation tends to produce such moral swinging, for better or worse (Berliner 2013). Yet, this also constitutes a good reminder that contradictions do not escape historical and cultural determinations. What I see as a contradiction hic et nunc might not be seen as such in different places and times.

What intrigues me the most is that humans may live peacefully with contradictions. Classical literature, it is true, is full of "split" tormented characters (think of Hamlet or MacBeth) whose divided selves display simultaneous multiple interior voices and antithetical values. Theorists of "double consciousness," such as W. E. B. Du Bois (2008), have lucidly described how African Americans, torn between striving forces, suffer from their double self in the United States. I, however, do not see my internal contradictions most of the time. They are "a-noetic." A relative self-ignorance-a kind of "selective laziness" about our own arguments (Trouche, Johansson, Hall, and Mercier 2015)_seems necessary to lead a peaceful life. Nevertheless, through reflexivity, contradictions may appear, like for my embarrassed feminist student singing a sexist song in front of her mirror. This aspect 
is a fascinating one for anthropologists. When social actors become conscious of their inconsistencies, whether it happens alone or in the midst of social interactions, "self-awareness" takes place. Unconscious processes that exist beyond actors' reach become conscious. This is what I would call "reflexivity-in-action." These are moments during which self-knowledge and feeling about the self are being produced. As anthropologists, one might want to try to capture them. Methodologically, this requires building intimate ties with our interlocutors and can only be patiently accessed through long periods of ethnographic research.

Often, the breach created by self-awareness leads to the production of justifications in order to create consistency. For the anthropologist, there is always the use of cultural relativism to explain why some of our behaviors and statements in the field contradict others at home. Although one should not underestimate the existence of lies, dissimulations, and manipulations (especially in politics where "denying contradictions" constitutes an important skill), inconsistencies are often neutralized in good faith. Boltanski and Thevenot (1991) have masterfully investigated the working of these post hoc rationalizations. They have developed a "pragmatics of reflexion" and describe the social agent hovering between action and self-reflection, occasionally conscious and "in control," but often blindly caught in the contingencies of daily life. Morevover, our contradictory thoughts, feelings and attitudes are transformed over a lifetime. Nothing is fixed in marble here. As anthropologist Richard Wilk looking at his own contradictions exclaims, "I tried to give up smoking for 15 years, and now I eat too much for my own good" (Wilk 2001: 276). In some cases, self-awareness triggers the adoption of new ideas and attitudes. It can cause a "moral breakdown" (as Jarrett Zigon puts it), i.e. "those social and personal moments when persons or groups of persons are forced to step-away from their unreflective everydayness and think-through, figure out, work on themselves and respond to certain ethical dilemmas, troubles or problems" (Zigon 2007: 140 ), and be a source for personal and cultural invention.

Above all, the topic of contradictions, which I have only briefly touched upon here, is an important one for anthropologists as it invites us to reflect on the notion of a unified self. Experiments in philosophy have shown that the idea of "stable personalities" is questionable. "There is no hardcore personality, stable, unified, invariant from one situation to another," writes French philosopher Ruwen Ogien (2011: 40, my translation). Seemingly trivial factors can guide our behavior in a moral way or in another, such as how the smell of warm croissants in a supermarket may trigger empathy for a beggar and the desire to give him money. How, then, to account for the coherence of the self? Or, as Paul Roubiczek asks, "How can we reconcile the innumerable contradictions we are unable to resolve with our longing for a unitary coherence which also seems essential part of our true nature?"1

Unfortunately, I have no solid answer to this question. I do, however, have a suggested path to follow. For anthropologists, I believe, it is time to bring back ambivalent statements, contradictory attitudes, incompatible values, and emotional internal clashes as research objects. It is also essential to outline a typology of different contradictions as well as to explore the cognitive, emotional, and social processes through which they are rendered possible in human lives. In particular, it is

1. Available WWW: http://thinkinginopposites.tripod.com/contents.html. 
worth investigating how actors themselves live with and justify their contradictory thoughts and behaviors. But we must do so with care, always keeping in mind that, to borrow Nietzsche's formula in Beyond good and evil ([1896] 1966: 154), contradictions are "signs of health; everything absolute belongs to pathology."

\section{On contradictions}

Michael Lambek

David Berliner raises many issues in his remarks about contradiction. In brief response I restrict myself to two observations: namely that, on the one hand, while there has been no comprehensive discussion of contradiction within anthropology, the concept has made a recurrent appearance in the discipline, and on the other hand, anthropological work suggests limits to the application of the concept.

To begin with, there is the admonition that was given to all prospective fieldworkers when I was young: "be careful to distinguish what people say from what they do." One could break it down further: distinguish what they say they do from what they say "one" does or "one" should do. The approach to ethics that I and others have advocated addresses, in part, how people themselves address these gaps. If some contradictions are repressed or passed over in silence and others deeply felt, more commonly, as Berliner suggests, there are ways of living with them and living with oneself.

It is also the case, as I think both Evans-Pritchard (1937) and Bourdieu (1977) observed, that what appears contradictory when abstracted in the observer's or analyst's model-laid out like museum objects in E-P's image-is not so from within practice or the perspective of the practitioner. For one thing, time and attention play a role and we do not hold all our ideas in our consciousness at once. I examined this at another level of scale by contrasting what I called forensic and mimetic forms of personhood, the former insisting on personhood as something continuous and consistent over a lifetime and the latter not. Acts that appear contradictory from a forensic perspective could be understood quite differently from a mimetic one (Lambek 2015b).

Not all "contradictions" are of the same logical type and I am not sure that all Berliner's examples deserve the epithet. While propositions can be described as contradictory to one another or even internally self-contradictory, can the same be said for practices (like smoking and jogging or advocating for clean air) or for commitments (like to a partner and a profession, or even to one friend and another)? From a certain perspective these might be considered inconsistencies rather than contradictions. They could produce conflict (again different from contradiction) and the sense of being pulled in opposite directions-situations that get resolved through practical judgment and sometimes rupture. They could also lead to various tactics or strategies, including (unconscious) repression, (subconscious) rationalization, ambivalence, self-deception, (conscious) lying, or attempts at compromise. Often there are cultural means at hand to express and address these matters, such as the secondary rationalizations available in Zande witchcraft (Evans-Pritchard 
1937) or the irony and double stance afforded by Malagasy spirit possession (Lambek 2010, 2015a).

"Contradiction" qua concept plays a particular role in distinct bodies of theory, holding a different place in Marxism than in Freudianism, for example. We do see plenty of contradictions in the economic realm and the political one, not to mention in the rhetoric of politicians. But following philosophers like Ludwig Wittgenstein, John Austin, and Cora Diamond, most utterances (voiced phrases) are not in the form of propositions and hence not of the kind that submit easily to contradiction, at least not logical contradiction. As the pragmatic tradition in linguistic anthropology has elaborated, they are doing other things, and producing results or consequences related to but not the same as logical contradictions-for example, the double binds elaborated by Gregory Bateson (1972).

At the level of thought, Lévi-Strauss (1963) argued that binary oppositions are mediated in myth and through other intellectual and aesthetic means and media. However-and this is the core of my second point-more common than outright binary oppositions are incommensurables. By incommensurables I mean, following Kuhn (1962) and Bernstein (1988), things that cannot be compared along a single yardstick or according to any neutral external measure. Translated with respect to structuralism, this means they cannot be ordered according to a set of binary differences. Incommensurability is widely prevalent; for example, between "religion" and "science," between one religious tradition and another, between key words in one language and another (what Cassin 2014 refers to as "untranslatables"), and perhaps most generally of all, between language and the world (or at least the objects it purports to represent). Fundamentally, what Lévi-Strauss saw as an opposition between nature and culture (or that various systems of undomesticated thought can be understood as or by means of binary oppositions) can better be described as a relation between incommensurables. Whereas binary relations are constituent of structures, incommensurables are not in stable relation to one another; perception of their difference leads to ongoing (inconclusive) conversation or to the continuously postponed final resolution that Lévi-Strauss perceived in myth. One way to describe anthropology itself is as the domesticated conversation (or science) that emerges from or in respect to the incommensurability of nature and culture.

The anthropology of religion can be said to have advanced over the intellectualism of Tylor precisely insofar as new models of language have permitted us to see religious acts and utterances in a new light (Lambek 2013). Thus the application of metaphor, irony, and other tropes replaces literal readings of other peoples' utterances abstracted from the flow of action and conversation. And following Austin (1965), illocutionary utterances are not to be evaluated as true/false but with respect to what they do or bring into being. Poorly constituted illocutionary utterances are to be understood as infelicitous rather than contradictory. Rappaport (1999) both generalizes this to ritual and argues that the most sacred utterances are ones not subject to refutation (hence to contradiction). Likewise, category mistakes-which are widely prevalent and possibly unavoidable-are not the same as contradictions.

The fact of differences in the world-whether understood as contradictory, oppositional, or incommensurable-leads to the following in practice: we can attempt to select exclusively one or the other ("either/or") or we can try to select 
both ("both/and"). Each of these paths has consequences and in the end there are higher-level logical quandaries or paradoxes as when, along the either/or path the discarded difference returns or resurfaces in various disguises, or when, along the both/and path we realize that both/and comprises both itself and the either/or option. Hence we have complexity and incompletion (irresolution) in thought and practice. In Mayotte, I have argued (1993), the "conversation" between spirit possession and Islam can be characterized as one in which Islam (i.e. certain arguments made by Muslims and as Muslims from within an Islamic tradition) asks people to select "either/or" with respect to certain practices, whereas spirit possession offers a world of "both/and" - one in which you can practice both, in which not only can a Muslim be a spirit medium, but some of the spirits too are Muslim. Here then we have a practical articulation between two traditions, one of which sees them as mutually exclusive or contradictory and the other does not. Insofar as the latter comprehends Islam, it acknowledges Muslims who do practice possession and such Muslims do live more or less happily with both traditions. The relation between the traditions is itself not one of outright contradiction but of incommensurability insofar as they have different starting points and cannot be measured against each other point by point. Moreover, the traditions themselves develop internally differentiated conversations with respect to their relations with one another. As in even the best literary translation there is always a residue. The residues are not only good to think with they are often what we think about.

The opposition between mutually exclusive either/or and comprehensive both/ and is widely prevalent in practice, sometimes explicitly in thought, and in certain domains possibly unavoidable. But how can we resolve whether this opposition is itself mutually exclusive or comprehensive? I have argued (Lambek 1998; cf. 2015c) that the mind/body opposition can be understood in these terms, such that we will never reach a decisive conclusion between the philosophical alternatives of dualism and monism (or non-dualism).

The worlds we inhabit are rich, interesting, and complex places. Our foundations turn out to be "turtles all the way down" (Geertz 1973); (in)finitude, irresolution (incompletion), and inconsistency are features of the human condition. For that very reason, our worlds are varied and unpredictable enough to make us want to stay around, keep talking, and see where the conversation turns next.

\section{Living by means of the law of non-contradiction}

\section{Richard Shweder}

Before anthropologists ever tried to interpret the Nuer utterance "a cucumber [A] is an ox $[\sim \mathrm{A}]$ " there were debates about whether the law of non-contradiction was a universal rule of reason. Lucien Lévy-Bruhl (1910) argued for its cultural specificity. He pointed to translations of statements by South American Indians who were reported to declare "We $[\mathrm{A}]$ are red parrots $[\sim \mathrm{A}]$ " or "Sorcerers $[\mathrm{A}]$ are bush cats [ A]." Lévy-Bruhl did not judge such statements to be illogical nor did he view them as indications that South American Indians were living with contradictions 
or possessed hybrid or split identities. Instead he posited the existence of an alternative non-rational mode of thinking which he labelled "mystic participation." Ultimately his own "ontological turn" led him down a path that brought him back to his senses and to an ontological return to the inescapability of the law of noncontradiction; being a sensible scholar Lévy-Bruhl recanted. My own view is that the law of non-contradiction describes a logical truth which is universally binding, and has real normative force everywhere. The law entails a cluster of absolute rules of reason. For example: contradictory propositions cannot both be true (at least not in the same sense and at the same time); nothing can be both itself (A) and not itself $(\sim \mathrm{A})$ (at least not at the same time and place); propositions that are unambiguous in their reference are either true or false and not both. Friedrich Nietzsche is quite mistaken: not everything absolute is in the domain of pathology. Indeed, intellectual well-being itself rests on the absolute rules of reason mentioned above. Examples meant to suggest otherwise that they are optional or culture-specific can usually be interpreted as either (1) tropes (for example, metaphors or implicit similes: a red-blooded former lover palpably asserts "I have a broken heart"; or a ritual specialist means a cucumber is like an ox in the following way and that feature of similarity is relevant in this context for the following reason ...), or (2) as parallel descriptive systems at two different levels of analysis (there is no contradiction if one asserts that "table salt is sodium chloride"), or (3) as bad translations and/or misunderstandings of native categories, discourses, contexts, or purposes.

The law of non-contradiction has universal normative force because it is an ultimate criterion for distinguishing between rational, irrational, and non-rational states of mind, and is an indispensable tool for constructing any and every picture of reality. The current excited embrace of contradiction associated with "the ontological turn in anthropology" must be limited: the very recognition by an anthropologist that one's representation of another person's (or people's) picture of the world is incoherent (and makes them look alien and mysterious) presupposes the operation of the law of non-contradiction; and incoherence is never evidence of the existence of either an alternative reality or an alternative view of the world.

Additionally, the scope of applicability of the law defines the boundary between objective (or genuine) moral arguments and subjective (or incommensurate and hence unarguable) declarations of value. This is so because a genuine argument requires more than just a difference in judgment between two or more parties in a conversation. A genuine moral argument requires that if one of the parties to the disagreement is right in judging $\mathrm{X}$ (a particular course of action by a particular person in a particular situation) to be wrong, bad, vicious, or immoral then the other party cannot be equally right in judging $\mathrm{X}$ to be right, good, virtuous, or moral. In other words what is presupposed by the very notion of a genuine dispute is that whatever difference in judgment exists is about something objective, which means that in principle the differences are resolvable because one or the other (or both) of the parties to the disagreement is either confused, ignorant, or in error about the facts of the matter or the terms of the disagreement. Getting the terms of any supposed disagreement straight is one of the benefits of living by the law of non-contradiction. It is not a violation of the law of non-contradiction if one person asserts that "souls transmigrate" and another person asserts that "souls do not transmigrate" if what the first person means to say is "Souls transmigrate in 
India" and what the second person means to say is "Souls do not transmigrate in the United States." It is not a violation of the law of non-contradiction if one person asserts "Souls transmigrate" and another person asserts "When you are dead you are dead" if the first person is referring to a posited spiritual essence of the self and the second person is referring to the material aspects of the human body.

The law of non-contradiction is thus a basic constituting and regulatory norm in the search for truth. It helps us draw the line between real disputes versus those differences that are merely matters of subjective taste (whether personal or collective). There can be a real dispute over the question "does the reshaping the genitals of girls in African ethnic groups typically eliminate their capacity to have a normal sexual life, including orgasms?" The answer to the question can't be both yes it does AND no it doesn't. ${ }^{2}$ In contrast (as the saying goes) in matters of taste (or mere opinion) there can be no dispute. For example, if the members of one ethnic group sincerely like the visual appearance of circumcised male genitals and the members of another ethnic group really don't like that look, then their aesthetic evaluations are different but not contradictory-both can be true.

The law of non-contradiction is such a fundamental, intuitively available, and automatically applied rule of thought that we rarely reflect on the many ways we presuppose its normative relevance, embrace its normative force, and actually succeed at putting it to work. We not only live by means of the law of non-contradiction. Its application enables the process of "compartmentalization" mentioned by David Berliner (with reference to the work of Roger Bastide). That is how we go about constructing our sense of reality.

Some brief remarks by the philosopher C. West Churchman are helpful in clarifying this point. Churchman (1961: 234) has the following to say about the law that nothing can be both itself $(A)$ and not itself $(\sim A)$. To paraphrase, the table before me is green and the table before me is black, which is not a violation of the law of non-contradiction because it is green on the top and black underneath. The illustration is an application and instantiation of the law: what non-contradiction means in this instance is that nothing can be both itself $(A)$ and not itself $(\sim A)$ in the same place and at the same time. "The entire top of the table appears to be green and the entire top of the table appears to be grey," is not a violation of the law of non-contradiction because it is green in appearance to me and grey in appearance to you (who is color blind). Again the illustration is an application and instantiation of the law: what non-contradiction means in this instance is that nothing can be both itself $(A)$ and not itself $(\sim A)$ in the same place and at the same time in the experience of the same person. "The top of the table is green and the top of the table is hard," is not a violation of the law of non-contradiction because it looks green to my eye but feels hard to my hand. This illustration too is an application and instantiation of the law: what non-contradiction means in this instance is that nothing can be both itself $(\mathrm{A})$ and not itself $(\sim \mathrm{A})$ in the same place and time and to the same person in the same aspect of his or her experience. Visual perception and tactile perception are separate "compartments" in the human sensorium and

2. There is now ample evidence to suggest that "No it doesn't eliminate their capacity to have a normal sex life, including orgasms" is the correct answer to that question (see Abdulcadir et al. 2015; Ahmadu 2009; Catania et al. 2007) 
it is not a contradiction for something to be both green $(A)$ and hard $(\sim A)$ to the same person. Reflecting on the law that nothing can be both itself $(\mathrm{A})$ and not itself $(\sim \mathrm{A})$, Churchman argues that it is intuitively available in our mental equipment and forces us to be active in ordering and recording our experiences. In fact, our experiences get structured through its application. At the same time the law gains content as it is used to construct a picture of reality.

I suspect the domain of contradictory thoughts, discourses, and attitudes that David Berliner has in mind in his introduction to this debate on "Anthropology and the study of contradictions" is far broader than violations of the law of noncontradiction and includes a wide variety of types of conflicts and tensions. I say this because those hybrids of the contemporary world mentioned in David's remarks (the "environmentalist smoker" or the feminist who enjoys listening to a catchy tune despite the offensive lyrics) do not seem to be obvious violators of the law of non-contradiction. One can add other examples. Scholars sometimes have ironic relationships to the topics they study: the world's leading expert on children's stories who hates children; the authority on the process of taking the perspective of others who is conspicuously egocentric. Nevertheless in none of those instances is the law of non-contradiction actually transgressed. Is the environmentalist smoker or the humanist trader sincerely endorsing two mutually contradictory propositions? Not really. I was inclined to interpret those illustrative hybrids as examples of a person's weakness of will (succumbing to temptation), or as instances of insufficient conscientiousness (lack of conviction, perhaps even hypocrisy) in the application of some unitary general principle which one ostensibly endorses, or perhaps even as evidence that some principles are justifiably bounded by context (that is to say "compartmentalized") and not designed to be general in their application.

Nevertheless David Berliner's creative provocation is the suggestion that, in the contemporary world, a new form of identity is on the rise: one defined by a form of self-consciousness that grants permission to oneself to sincerely embrace and accept contradictory propositions. For anyone who believes, as I do, that the law of non-contradiction is a universally binding law of reason, this raises the question: How in the world can, and why in the world should, one live with such contradictions? I do think there is something new and peculiar about aspects of the self-consciousness of the modern individual that begs for explanation. But I don't think it is the embrace of multiple or split selves. It is a unitary self that places the alarm clock on the other side of the room protecting itself in advance from any temptation in the morning to turn off the clock and stay in bed. That temptation or anticipated temporary personal preference is not evidence of the existence of multiple selves.

Modern individualism, however, does tend to produce a type of false consciousness that leads us to perceive contradictions in our own thoughts, attitudes, and actions that are more apparent than real. We tend to think of ourselves as context free prior to society, autonomous actors with personalities motivated by abstract mental states-for example, the assertive, courageous, fearless risk-taker. When we discover that the financial risk-taker in us is not a social risk taker or that the intellectual risk taker in us is not typically a physical risk taker, or that we are assertive with our peers yet highly deferential when interacting with our parents, we perceive those context-specific compartmentalized actions as contradictions within the self. The perception is an illusion created by the ideology of modern 
individualism and an overreliance on abstract mental state concepts to produce a non-relational reflective characterization of one's self. It is not a violation of the law of non-contradiction, however, to believe one should defer to the judgment of one's elders but not one's peers.

Other types of conflicts are quite real, even if they are not technically examples of living with violations of the law of non-contradiction. I suspect most politically liberal Americans would sincerely and happily embrace each of the following values when stated in the abstract: (1) Autonomy (the liberty of individuals to selfgovern, express themselves, and lead their lives free of external interference); (2) merit-based justice (fairness and non-discrimination in the distribution of costs and benefits such that there is proportionality between actions and outcomes, and you reap what you sow); (3) equal opportunity (or equal life chances to participate in the valued positions within a society); and (4) benevolent safekeeping of those who are downtrodden and vulnerable. The four values are not logically contradictory (one can ascribe "goodness" to all four) yet from a practical point of view they are agonistic (benevolent safekeeping places limits on the liberty of those who are cared for, just as providing for equal opportunity often interferes with merit-based justice) and it is an ethical pipedream to imagine that any one society or person can live a life that fully embraces all four values at the same time. In a world of objectively conflicting values one carries on bumping up against those value conflicts (equality versus liberty, for example), which in some (non-literal) sense or another one might portray as living with our contradictions. But even in the domain of values (autonomy, for example) it is not a violation of the law of non-contradiction to be in favor of "free speech" but opposed to "free trade."

Ultimately we have no choice, even in the contemporary world, but to live (and to argue with each other) by means of the law of non-contradiction. It is an indispensable rule of reason in any public policy debate. Let me close with an illustration from what I call "the genital wars." Here I quote from Shweder (2013: 349):

"Equal Rights for All Sexes: Say 'No' to Forced Genital Cutting!" is the gender equity position of contemporary anti-male circumcision groups in North America and Europe. These activist organizations hope to put an end to the circumcision of male minors, which they describe as genital mutilation and child abuse. They believe that the male surgery is physically and psychologically harmful to boys, and a violation of several human rights, including the right to self-determination and the right to the preservation of physical integrity. In their efforts to abolish the practice they are encouraged by the ubiquitous North American and European news reports, opinion pieces, and NGO advocacy literature denouncing customary female genital surgeries in Africa in precisely those terms; and by the ready embrace by legislators (and by several global organizations too) of legal statutes criminalizing female genital surgeries for minors (and in some countries in Europe even banning the procedure for adult women, if those women are motivated by a desire to uphold their own ethnic traditions). Simply put, the gender equity argument of the anti-male circumcision groups runs as follows: if it is reasonable to have public policies safeguarding the body of female minors from all medically unnecessary genital modifications, then the principle of gender equity (plus logical consistency) suggests there should be similar 
policies protecting the male body as well. Therefore, whenever global feminist organizations, public policy advocates, politicians or celebrities speak out against customary female genital modifications, denouncing them as mutilations and child abuse, so too they should speak out against customary male genital modifications, morally condemning them in similar terms; even at the risk of offending Jewish and Muslim supporters of anti-FGM campaigns. Put even more simply: there should be equal protection for boys and girls before the law.

This is a real and consequential dispute. No party to the argument is prepared to embrace a hybrid identity. Not the women of Sierra Leone or Egypt who favor genital reshaping for both girls and boys. Not the women of Holland or Germany who oppose genital reshaping for both boys and girls. And certainly not the outspoken critics of female genital reshaping in the United States or England who remain silent about the male case and may have even recently circumcised their own son. In a real dispute it is important to get ones facts straight; ${ }^{3}$ and if and when one engages in reliable fact checking the principle of fairness (treating like cases alike and different cases differently) requires that we do more than just live with our contradictions.

\section{Some Christian contradictions}

\section{Richard Irvine}

Confronted with a catalogue of contradictions-the evidence of everyday inconsistencies in human lives-it is easy to take an external position of analysis which makes the incongruity seem all too obvious. Surely anyone can see this is not consistent with that? Perhaps, once dissected and laid out as specimens, the contradictions seem stark. But are they experienced this way when lived out in real time?

Timothy Jenkins (2013: 57), in his re-reading of When prophecy fails (Festinger et al. 1956), asks "do we rationalise except when challenged?" Festinger and the team of researchers who investigated a group predicting the end of the world did so to see what would happen when the prophecy did not come to pass: "Suppose an individual believes something with a whole heart; suppose further a commitment to this belief, suppose irrevocable actions have been taken because of it; finally, suppose evidence, unequivocal and undeniable evidence, that the belief is wrong: what will happen?" (Festinger et al. 1956: 3). Such a scenario is theorized as a cognitive dissonance: an inconsistency between cognitions that will produce discomfort; in the wake of this discomfort "there will arise pressures to reduce or eliminate the dissonance" (ibid.: 28). Jenkins, tracing the interactions of the group being studied,

3. In this instance fact checking has not been the strong suit of anti-"fgm" activist and advocacy organizations or the media, which is a point emphasized by the Public Policy Network on Female Genital Surgeries in Africa (2012). See their Hastings Center Report titled "Seven things to know about female genital surgeries in Africa." See also Shweder (2013). 
the researchers, and the press, makes the important observation that the processes being described here appear social rather than cognitive in nature-and, indeed, that "the observers took an open hand in shaping events, precipitating reinterpretation ... encouraging, pressing, questioning" (Jenkins 2013: 53); after the failure of the predicted arrival to materialize, it was the researchers who repeatedly pushed group members by pointing out the apparent inconsistency, thus strongly encouraging the generation of rhetorical rationalizations. In noting that in the account "there is little or no evidence of any cognitive or mental process; this action all takes place at the level of rhetoric" (ibid.: 57), Jenkins draws attention to the circularity of the analysis of cognitive dissonance: "behaviour is held simultaneously to be evidence for the inner event and to have been produced by it" (ibid.: 8).

Indeed, it is worth noting the manner in which Festinger outlines his theory of cognitive dissonance. Having set out with a list of examples of inconsistencies, he then attempts an all-important maneuver: "First, I will replace the word 'inconsistency' with a term that has less of a logical connotation, namely, dissonance. I will likewise replace the word consistency with a more neutral term, namely, consonance" (Festinger 1957: 2-3). In this move, Festinger is able to shift from signifying an external observation of what appears inconsistent, to the imputation of an internal state, namely dissonance. Inconsistency is not just something observed, but a phenomenon that is experienced, and furthermore this experience is one of discomfort. The anthropological problem with this is twofold. Firstly, the shift of analysis from observed inconsistencies towards a mental state draws our attention away from the varied social processes that might generate the inconsistencies-in this respect, I would suggest that what is needed is a taxonomy of contradictions rather than a singular diagnosis. Secondly, it begs the question: do people really experience apparent inconsistencies as "dissonance?"

Ethnographically, we may find that the role of apparent contradictions in social life does not have the character of dissonance, but instead inconsistencies might tend towards peaceful coexistence, or may even be mutually constitutive in ways that cannot be construed as "the reduction of dissonance." As an anthropologist of religion who has carried out research on Christianity, here I wish to focus on a number of apparent contradictions that play an important role in Christian life (not because I believe they are necessarily unique to Christianity, simply that because of my ethnographic experience I find Christianity a useful lens through which to view this topic). My contention will be that such "contradictions" are not instances of disequilibrium to be rectified, but are often the very heart of the matter and, indeed, may be sustained as contradictions.

One important manifestation of contradiction flies under the banner of "Theological Correctness," a term coined by Barrett (1999) to account for the coexistence of multiple levels of representation of theological concepts. Barrett and Keil (1996), in experimental studies with US College Students, found that while God was conceptualized in abstract ways in contexts that elicited reflections on theology, the same God was conceptualized in naturalistic and anthropomorphic terms in contexts that described His actions in the world. The students tended not to place God under psychological or physical constraints in questionnaires about doctrine; rather, in story tasks about God acting in the world, the students recalled and paraphrased the stories in ways that drew heavily on anthropomorphic conceptions: 
a God not free of constraints but, rather, modeled on human agency. "At least on one level, the problem created by the ontological chasm between humans and the supernatural is solved by ignoring the difference. . . The problem is addressed by creating God in the image of ourselves, and using the constraints of nature and humanity as our basic assumptions for understanding God" (ibid.: 244).

For Barrett (1999: 327) such a conclusion reflects the widespread use of multiple levels of representation in Christian life. "Among Christians, God is simultaneously non-physical, formless, and omnipresent; but also occasionally thought of as an old man living in the clouds." Such an apparent contradiction is accounted for in part by the different contexts in which knowledge of God is used. While abstract properties are important for theological reflection, "these types of properties make for difficult inference generation in many everyday, information processing tasks" (1999: 331), leading to the use of more intuitive categories. (Such multiple levels of representation are not restricted to religious thought; see, for example, Kelemen et al. [2013] on the use of teleological explanations, e.g. "Trees produce oxygen so that animals can breathe," as an intuitive model among physical scientists thinking under time pressure, when those same scientists explicitly reject such explanations in contexts where they are able to reflect and set out what they see as the scientifically accurate position.) Barrett (1999) makes it clear that we risk distorting religion if we fail to take account of the operation of these multiple levels of explanation; they may appear contradictory, but they coexist in the process of applying religious understanding to a breadth of circumstances.

As I have carried out ethnographic research on Catholic monastic life, one attraction of this "theological correctness" approach is that it might point us towards an understanding of the relationship between the epistemology of God that frames mystical prayer and that implied in other domains of monastic life. The English Benedictines with whom I worked emphasized their apophatic tradition; that is, a non-imagistic and non-conceptual approach to prayer, a focus "on God the unknown ... rather than the ways we picture him." Such an approach is sometimes described as a "via negativa." In this context, any means of representing God is seen as inadequate-God is beyond our understanding and narrow sensory capabilities. Yet in the daily routine of monastic life, God is constantly engaged with in ways that draw on positive representations rather than this "negative" sense of the God that cannot be known: the language of the liturgy, of preaching, and of everyday allusions to His actions in the world. Indeed, these multiple layers of representationthough apparently contradictory-often appear to exist in relation to one another. Denys Turner (1995) in his work on negativity in Christian Mysticism focuses his attention on the rich language used in texts that promote apophatic mysticism; metaphors of "exteriority," "interiority," and "ascent" are central to the description of the progress of the soul toward God, and the image of "darkness" is key. For Turner these should not be taken as after-the-fact descriptions of a mystical experience, but rather are statements of an "anti-mysticism" that seeks to use language self-subvertingly. These are descriptions that deny the possibility of description, a process resonant with the "active cultivation of the awareness of ignorance," which Mair (2015: 252) describes in the context of Inner Mongolian Buddhism.

This is important because it seeks to show that the apophatic focus on "God the unknown" does not stand alone, but exists in a mutually constitutive relationship 
with positive images of God in the process of insisting upon their failure. As the Irish Dominican Conor McDonough explains it, this is grounding silence in speech (McDonough 2011: 72); "the abandonment of all speech is an essential element of our return to God, but such abandonment can only take place by first adopting the divinely legitimated speech of scripture and the liturgy" (ibid.: 73). This is a process that does not just live alongside its contradictions, but unfolds through them.

A further issue raised by this example of the "place" of mysticism among activities that seem, at least on the surface of it, to pull in a very different direction is the question of the interconnection between the ultimate relationship with God and the means by which one engages in daily routine. Or, to put it another way: Latour (2002) may evoke an understanding of religious language through allusions to the intimate language of lovers, but lovers living together in a long term stable relationship still have to make shopping lists and have conversations about the domestic budget.

Louis Dumont (1982: 6) draws attention to the effect of the New Testament teaching of the "individual-in-relation-to-God." The individual soul has eternal value through its relationship with God, and this "infinite worth of the individual is at the same time the disparagement, the negation in terms of value, of the world as it is: a dualism is posited, a tension is established that is constitutive of Christianity and will endure throughout history." While there is a recognition of earthly duties, these are relegated to second place. "The worldly order is relativized, as subordinated to absolute values" (1982: 7). This relativization is exemplified, for Dumont, in Jesus' teaching "Render unto Caesar the things which are Caesar's, and render unto God the things that are God's" (Matthew 22:21; Mark 12:17; Luke 20:25). Such worldly matters are seen as a small thing when placed in the context of a destiny of union with God.

One source of this relativization is temporal. Dumont notes the "millenarist" context of such teaching, with the second coming of Christ and the end times expected imminently. This allows for a radical discontinuity between worldly concerns, which were soon to cease, and ultimate concerns about the continuing individual relationship with God to be lived out in the "new heaven and the new earth." Yet 2,000 years on, the world has not yet ended. It is still there for believers to live in. The issue here is not one of "managing dissonance," but rather the challenge of working across multiple timeframes. Albert Schweitzer's use of the term "interim ethic" (Interimsethik) to describe the ethical model proclaimed by Christ is expressive of this problem. Based on a detailed analysis of the teaching of Christ as expressed in the canonical gospels, Schweitzer (1925) sees Christ's ethics of service and humility as fundamentally conditional: "If the thought of the eschatological realization of the Kingdom is the fundamental factor in Jesus' preaching, his whole theory of ethics must come under the conception of repentance as a preparation for the coming of the Kingdom" (ibid.: 94). In contrast to "modern ethics," which Schweitzer argues is "'unconditional', since it creates of itself the new ethical situation. ... an end in itself" (ibid.: 99-100), Christ's ethical teaching of the gospels is "conditional', in the sense that it stands in indissoluble connection with the expectation of a state of perfection which is to be supernaturally brought about" (ibid.: 100). This coming of the Kingdom was "close at hand," and such conditional ethics were an interim measure in preparation. Their application to social problems over an extended period of time was not the central issue. 
The problem then becomes how to render such interim ethics as a continual state of living in an ongoing world. This apparent temporal contradiction recurs in the history of Christianity; for example, Victor Turner (1969), in offering a reading of the history of the Franciscans as a story of liminality and reaggregation, seeks to show how the radical nature of Franciscan poverty became institutionalized within the structures of the Church as St. Francis' order sought to maintain its form over time (ibid.: 153). The initial impulse is shaped by the immediacy of the relationship with God: "time and history, however, bring structure into their social life and legalism into their cultural output" (ibid.: 153-54). And indeed, Christian life in its many varied forms is constituted by this dynamic of being both immediate and sustained, worldly and other-worldly. As a force in history it does not just live with such apparent inconsistencies, but takes shape through them.

But to return to the problem with which I started: is this experienced as a contradiction, or simply something that the external observer might flag up as an apparent inconsistency? As highlighted earlier in this forum, one classic anthropological approach to this question is the principe de coupure (Bastide 1955), drawing attention to the ways in which we engage in apparently contradictory behaviors without inner conflict. Examples such as those I have highlighted here-the deployment of different God concepts, or different ethical frames-may well be treated as examples of such compartmentalization. Yet this should not cause us to lose sight of the potency of contradictions when the elements that apparently contradict one another are brought into communication: the dynamic of self-subverting mystical language that emerges when mystics ground silence in speech, or the dynamic of institutionalized renunciation. To be clear: such "inconsistencies" are not necessarily experienced as dissonances, but we should be attentive to the social processes that take apparent inconsistencies (such as those at the heart of Christianity) and bring them into dissonance, often in generative ways.

I would point to Søren Kierkegaard's increasingly strident broadsides against "Christendom," issued during the last two years of his life (1854-1855), as a valuable resource for anthropologists attempting to think about this potency of contradiction. At the heart of his "Attack upon 'Christendom" is the attempt to bring into the light of day a classic case of compartmentalization: that of the Sunday Christian. Those who "in a quiet hour, with smothered sobs" declare that there will be "an eternal accounting," only to go back to seeking advantage and advancement immediately afterwards (Kierkegaard 1944: 87). Yet Kierkegaard goes to great pains to point out that he has nothing but gratefulness for those whose contradictions he singles out-they are precious because they allow for contrast: "the concept 'Christian' is a polemical concept, and one can only be Christian in contrast or contrastedly" (ibid.: 127). "Take an emetic, come out of the lukewarmness" (ibid.: 87), Kierkegaard urges. And it is the contradiction that, when confronted, serves as the emetic: it is, in this sense, remarkably productive.

Perhaps it is the case that we are hybrids. I personally find the word hybrid less exciting, less likely to capture my imagination, than the image of those strange mythological creatures composed of the parts of several animals. Such as this one from Andover in Hampshire (Gillett 1917: 11): "a duck laid an egg in a crypt under the Abbey. On this egg a toad sat, and as a result a cockatrice was hatched, which inhabited the vault and grew to an enormous size, and killed and ate anybody who 
entered there; all the time the nuns being in terror lest it should get out." The solution: to lower a great mirror into the vault. And so the cockatrice fought itself. One may well say that it lived with its contradictions.

\section{The minimality, contradictions, and origin of indifference}

\section{Albert Piette}

In David Berliner's text, there are two points that particularly interest me. The first concerns the assessment of the difficulty of capturing inconsistencies and contradictions of daily life, and the scarcity of anthropologists who attempt to do this. The second concerns the reasons why humans tend to multiply, tolerate, and accept a variety of contradictions.

\section{Modes of presence}

I will try to address the first point by suggesting a set of notions, which could help highlight the range of contradictions that I have encountered during my fieldwork in a religious context (Piette 2015b). As David Berliner mentioned, it is a special laboratory for observing contradictions. It is in fact this fieldwork (in French Catholic parishes) that allowed me to observe human modes of presence and to develop some methodological and theoretical points about this subject. And if, according to Berliner's accurate assessment, anthropologists have not placed much emphasis on these contradictions of everyday life, it is perhaps because they are specifically working on activities and relations or interactions, and they have not meticulously examined human modes of presence in their day-to-day. In this perspective, it would in fact be necessary to adopt "an individual-centered perspective." From a methodological point of view, this would imply observing one person at a time in order to pinpoint the different kinds of contradictions, through the succession of moments and situations, and perhaps conduct introspective interviews, for example, to shed light on the non-reflexive dimension (Vermersch 1999).

If one takes a close look at human presence, one is surprised by the number of details and inconsistencies. The set of notions I propose can help pinpoint and situate the contradictions and inconsistencies of which Berliner speaks, and which accumulate with the passing of moments. What is a human presence? How are humans present in the world? A human presence is usually made up of a large number of heterogeneous details, that is to say things that are as unimportant to the individuals who carry them as they are to their fellow participants in the situation or outside observers. The reality of action is, on the one hand, a body in the process of moving, accompanied by sideways glances and peripheral gestures, and on the other hand a state of mind that often has nothing to do with the action in progress. It is the minor mode of realty. Initially, this point can be useful for describing the real, concrete person, getting the clearest possible view of his or her variations of intensity. But beyond these details which are constant in human presences, there 
is a kind of minimality that is not just a matter of noticing distracted attention. It does not just concern secondary layers of presence, but the whole presence in the action. It is the natural attitude of humans not completing their actions and letting themselves be penetrated by contradictions and their meaning. To take account of this, I specify four characteristic elements, and their respective opposites (Piette 2015a). They make it possible to incorporate many contradictions of existence, but also the possibility of becoming aware of them and making changes, as David Berliner says in his text.

The first characteristic of human presence is cognitive economy. This presupposes routines and the automatic performance of sequences of actions without the need for deliberation and without reference to an instruction. Cognitive economy is also connected with the presence of mental patterns that enable the particular state of a situation to be assessed, thus generating appropriate actions almost automatically. This facility reflects the central role of material supports in the form of various signs (including writing and language) lightening the work involved in social negotiation, suspending-or in any case minimizing - the need to negotiate or create new relations. This economical mode of presence places in the background any potential ordeal that a breach would cause to swiftly return to the foreground; in this way it de-intensifies the consequences and power of some of the situation's supports. Moreover, the variety of potential and real information in a situation makes it impossible for a person to apply ideal norms of rationality (Cherniak 1986). Before making a decision, it is difficult for the person to make a rational calculation based on the information at his disposal. He cannot check the quantity of contradictions. He cannot verify all of the surrounding sources of information and can only count on already-known clues, as well as habits and previous experiences that enable him to assess the expertise and trustworthiness of a given interlocutor or datum and then make a quick decision. In addition to habit and the ability to set certain matters aside, trust is an expression of this economy. The opposites of cognitive economy would therefore be evaluation and decryption "work," thought and emotion in their various forms. Cognitive economy is lacking precisely when a novice is discovering a new situation, activity, or object (for instance Searle 1983). But it is also lacking in people who bring into play, in a maximal and very determined form, their ability to evaluate, judge, and draw meaning.

Docility, the second form, corresponds to the possibility of reposing upon existing supports (also upon contradictory values) rather than changing them, and accepting what happens. It implies a kind of tranquillity, whereas the desire, will or need to change and question (rules, human or material reference points) risks generating cognitive, emotional, or moral tension. The act of changing a situation can bring about at least a reproach, in any case the need for a justification and the risk of disagreement or conflict. The enactor of the change will maybe answer questions asked by evaluators or various experts. Docility is often an easier form of presence, but not necessarily.

Fluidity is the third form. It generates a kind of loosening and a certain tolerance of compromises, contradictions and inconsistencies ${ }^{4}$. Fluidity also translates

4. See the work of Steven Mithen (1996) who posits cognitive fluidity as a specificity of Homo sapiens. 
into various forms of making light of a situation, such as humor or irony. This looseness is not the game to be played with its rules, but the "slackening" of roles, creating another kind of play, like a machine with loose screws. Fluidity also corresponds to the possibility of easily shifting from one situation to another and effortlessly traversing activities that are sometimes very different, connected as they are with regulatory principles that would be incompatible in a situation of simultaneity. This shifting is made all the more possible insofar as within an activity, elements not relevant to it can arise in the form of details that enable it to be interwoven with previous or subsequent situations, and insofar as the person's aptitude for fluidity is supplemented by a particular ability to stay just below the level of consciousness, as well as forget his previous presences from one activity to another. Fluidity is directly connected to skills already acquired - the accumulated know-how that the person uses or effortlessly adapts to the situation. At all of these levels, it is rigidity and inflexibility that are the opposite of fluidity.

Distraction, the fourth form, corresponds to this cognitive specificity of connecting a distracting being, object, or event with the status of a detail, thus avoiding compromising the minimal attention the situation requires. There are certainly different forms of distraction, such as detachment accompanied by an air of absence, or distraction provoked by external noise (sunshine or a stain on the wall), but distracting elements are only such because they do not constitute a sharable engagement model. Since they are only tolerated, they cannot become behavior to imitate. The opposite of this light form of distraction is just as much concentration as the loss of concentration.

In human presence, the proportioning of "work" and "repose"-indissociable from one another-is of course different for each person in a shared situation. It is important to emphasize this mixture. And over a set of successive activities, depending on what they are, a specific individual will pass through variations of proportion between work and repose. When people are very active, they remain "carried" by the continuity of moments and the presence of points of reference and other supports. There is no active dimension (evaluating, changing, losing, scheming ... that is not accompanied by at least one of the other constitutive "repose" dimensions. The elements of repose enable the infiltration of contradictions and also their acceptance.

Here, I would like to add another point of debate with David Berliner. These different points make it possible to stress a kind of equilibrium that individuals establish in most of the situations of their day-to-day continuity: from my point of view, this equilibrium allows a certain personal unity to be maintained beyond the various contradictions and beyond their different selves.

\section{The origin of indifference}

"Humans are full contradictions," David Berliner writes. They are constantly ready to express, create, and accept many contradictions in their own life and in others' lives. What would be the origin of this situation? This is the second question. Let me suggest a hypothesis (I stress this word), a kind of narrative of origin that takes us back to prehistory. What if prehistory were the beginning of contradictions? 
What fascinates me about humans most is precisely this daily suspension of lucidity, this indifference: not really thinking, thinking but not too much, not really knowing, accepting contradictions, according to the examples given by David Berliner. For 100,000 years, maybe more, human beings, Homo sapiens, have been living with the risk presented by intelligence, consciousness (especially reflexive consciousness), and the ability to know what they are doing, and also to think about time passing, about death, that of others and their own death, which they know they cannot escape. It is the risk that this intelligence might threaten life. Incidentally, this risk with its consequences might be the one that Neanderthal Man was defeated by and Modern Man, Homo sapiens, avoided. It is a hypothesis.

What happened? It can be said that animals live in a world in which perception and action take place without much gestural and cognitive laterality, maybe without contradictions. Conversely, species of the genus Homo gradually develop some temporary forms of distance. These are more perceptive and behavioral than existential, directed toward the immediacy of the situation, and thanks to housing, the presence of objects and the use of material signs, identity, and recognition marks. Then appears the particular and fascinating case of Neanderthal Man, which can help us learn a lot about the specificity of Sapiens. The graves of Neanderthal Man indicate a consciousness of time and death. Was his lucidity disturbed by the fact that he was incapable of neutralizing his consciousness not only of death but also of everyday contradictions, which might explain his extended evolutionary stagnation? He would have been both too intelligent and not intelligent enough! Would Neanderthal Man's failure lie in being aware of his mortality, being "too" lucid when it came to his mortality and the various contradictions of existence?

Let us briefly clarify the analysis. Neanderthal Man, who knows he will die, takes care of the dead. But this is what is interesting: contrary to traditional views, some prehistorians agree that Neanderthal graves are not accompanied by offerings. ${ }^{5}$ However, there are offerings in the graves of Homo sapiens, which were contemporary to those of Neanderthals. My hypothesis is to associate Homo sapiens with a specific ability that Neanderthal Man would not have acquired: to imagine the dead man as still alive, not only as an ex-living man but as living a new life. The offering would hint at the belief in this new life after death, but would of course not confirm it. It implies the cognitive ability to associate two contradictory qualities, death and life. Thus, Homo sapiens would have become able to make statements combining contradictory categories (for instance, the dead person is alive or the stone is a spirit), thus giving his assent to these. Let us say that he then believes in it: "What if he were still alive! What if this were true!" The act of believing has just spring up, but also at the same time-and especially - the need not to take this particular statement to its limit, the ability to accept its uncertainty.

And everything would have changed. Humans accepted not being certain, not deeply understanding this contradictory statement. They later learn halfconsciousness and cognitive looseness. Let us imagine a day-to-day life in a time and space where reserve, indifference and distance are learned and gradually become new cognitive skills for humans, who use them in other areas of activity and thought. The ability to accept indecision, not to take things literally, but also-and

5. See bibliographical references on this debate: Piette 2015b, and in French, Piette 2013. 
unfortunately-not to be lucid, not to face reality, becomes more widespread. Another world has just emerged, with the possibility of many contradictions and much indifference. The religious phenomenon is not only a special laboratory for observing everyday inconsistencies, as David Berliner says, but it would also be the birthplace of this mode of presence.

The act of believing has thus generated a new cognitive skill: mental looseness. It comes from the mode of being in which one is hypolucid towards mental and discursive associations between unbelievable things, a mode that has spread to all human activities. Humans practice the minimal use of consciousness; they know to what extent they can be conscious, and know what they cannot be conscious of. Conversely, Neanderthal Man lacked hypolucidity and lived with the difficult consciousness of contradictions, under stress when different kinds of contradictions occured. This is why I cannot say, as one often reads, that humankind, Modern Man, has made a triumphant departure from animality. If he has departed from anything, it is from other species of the genus Homo and this departure is in no way triumphant, since his success (in any case his survival until now) has been achieved through a cognitive looseness.

Religious statements, while generating a new mode of human living, also gave rise to a new form of reassurance, and this soon confronted humans with the need for stability, anchoring, and transmission. And this is the point: they were then faced with the risk of stabilizing, and therefore absolutizing and forgetting that it was only a belief in an incredible statement . . . since humans had just learned to suspend, postpone, and thus forget. This is the risk of too much looseness, which Sapiens would have gradually fallen into. For this reason all indifferences, including obeying an order to kill (according to David Berliner's example) are possible, in and between each action and situation. Could humans be the only ones to be contradictory and accept their contradictions indifferently?

David Berliner's wish is to observe and understand "ambivalent statements, contradictory attitudes, incompatibles values, and emotional internal clashes.” By proposing a conceptual framework and shedding light on the universal and specific dimension of human existence in all its contradiction and inconsistency, my reflection here has aimed to show the importance of this "science of contradictions."

\section{References}

Abdulcadir, J., Botsikas, D., Bolmont, M. and P. Petignat. 2016. "Sexual anatomy and function in women with and without genital mutilation: A cross-sectional study." The Journal of Sexual Medicine 13: 1-12.

Ahmadu, F. S. 2009. "Disputing the myth of sexual dysfunction in circumcised women." Anthropology Today 25 (6): 14-17.

Austin, J. L. 1965. How to do things with words. Oxford: Oxford University Press.

Barrett, Justin L. 1999. “Theological correctness: Cognitive constraint and the study of religion," Method and Theory in the Study of Religion 11 (4): 325-39. 
Barrett, Justin L. and Frank C. Keil. 1996. "Conceptualizing a nonnatural entity: Anthropomorphism in God concepts," Cognitive Psychology 31 (3): 219-47.

Bastide, Roger. 1955. “Le Principe de coupure et le comportement afro-brésilien.” In Anais do XXXI Congresso internacional de Americanistas, 493-503. São Paulo: Editora Anhembi.

Bateson, Gregory. 1972. Steps to an ecology of mind. Chicago: University of Chicago Press

Bazin, Jean. 2008. Des trous dans la joconde: L’anthropologie autrement. Toulouse: Anacharsis.

Berliner, David. 2013. "Le désir de participer ou comment jouer à être un autre." L'Homme 206: 151-70.

Berliner, David and Ramon Sarro. 2007. Learning religion: Anthropological approaches. London and New York: Berghahn Books.

Bernstein, Richard J. 1988. Beyond objectivism and relativism. Philadelphia: University of Pennsylvania Press.

Boltanski, Luc and Laurent Thévenot. 1991. De la justification: Les économies de la grandeur. Paris: Gallimard.

Bourdieu, Pierre. 1977. Outline of a theory of practice. Cambridge: Cambridge University Press.

—.2004. Science of science and reflexivity. Cambridge: Polity Press.

Cassin, Barbara, ed. 2014. Dictionary of untranslatables: A philosophical lexicon. Princeton: Princeton University Press.

Catania, L. L., O. O. Abdulcadir, V. V. Puppo, J. B. Verde, J. J. Abdulcadir, and D. D. Abdulcadir. 2007. "Pleasure and orgasm in women with female genital mutilation/cutting (FGM/C)." The Journal of Sexual Medicine 4 (6): 1666-678.

Cherniak, Christopher. 1986. Minimal rationality. Cambridge: The MIT Press.

Churchman, C. W. 1961. Prediction and optimal decision. Englewood Cliffs, NJ: Prentice-Hall.

Dennett, Daniel and Linda LaScola. 2010. "Preachers who are not believers." Evolutionary Psychology 8 (1): 122-50.

Du Bois, W. E. B. (1903) 2008. The souls of black folk. Radford, VA: Wilder Publications.

Dumont, Louis. 1982. "A modified view of our origins: The Christian beginnings of modern individualism," Religion 12 (1): 1-27.

Evans-Pritchard, E. E. 1937. Witchcraft, oracles, and magic among the Azande. Oxford: Oxford University Press.

Festinger, Leon. 1957. A theory of cognitive dissonance. Stanford: Stanford University Press.

Festinger, Leon, Henry Riecken, and Stanley Schachter. 1956. When prophecy fails: A social and psychological study of a modern group that predicted the destruction of the world. Minneapolis: University of Minnesota Press.

Freud, Sigmund. 1938. "The splitting of the ego in the defensive process." In Miscellaneous papers, 1888-1938. Vol. 5 of Collected Papers, 5 vols, 372-75. London: Hogarth and Institute of Psycho-Analysis, 1924-1950. 
Geertz, Clifford. 1973. The interpretation of cultures. New York: Basic Books.

Gillett, M. 1917. Folklore, legends, and superstitious customs in connection with Andover and neighbourhood. Andover: Standard Printing Co.

Good, Kenneth (with David Chanoff). 1991. Into the heart: One man's pursuit of love and knowledge among the Yanomami. New York: Simon \& Schuster.

Harvey, David. 2014. Seventeen contradictions and the end of capitalism. London: Profile Books.

Jenkins, Timothy. 2013. Offlying saucers and social scientists: A re-reading of when prophecy fails and of cognitive dissonance. New York: Palgrave Macmillan.

Keane, Webb. 2016. Ethical Life: Its natural and social histories. Princeton, NJ: Princeton University Press.

Kelemen, Deborah, Joshua Rottman, and Rebecca Seston. 2013. "Professional physical scientists display tenacious teleological tendencies: Purpose-based reasoning as a cognitive default." Journal of Experimental Psychology 142 (4): 1074-83.

Kierkegaard, Søren. 1944. Attack upon "Christendom.” Translated by Walter Lowrie. Princeton: Princeton University Press.

Kuhn, Thomas. 1962. The structure of scientific revolutions. Chicago: University of Chicago Press.

Lambek, Michael. 1993. Knowledge and practice in Mayotte: Local discourses of Islam, sorcery, and spirit possession. Toronto: University of Toronto Press.

1998. "Body and mind in mind, body and mind in body: Some anthropological interventions in a long conversation.” In M. Lambek and Andrew Strathern (Eds) Bodies and persons: Comparative perspectives from Africa and Melanesia, edited by Michael Lambek and Andrew Strathern, 103-23. Cambridge: Cambridge University Press.

2010. "How to make up one's mind: Reason, passion, and ethics in spirit possession." University of Toronto Quarterly, Special Issue on Models of Mind, edited by Marlene Goldman and Jill Matus, 79 (2): 720-41.

2013. "Varieties of semiotic ideology in the interpretation of religion." In A companion to the anthropology of religion, edited by Janice Boddy and Michael Lambek, 137-53. Malden, MA: Wiley Blackwell.

2015a. "Rheumatic irony: Questions of agency and self-deception as refracted through the art of living with spirits." In The ethical condition: Essays on action, person \& value, 150-70. Chicago: University of Chicago Press.

_. 2015b. "The continuous and discontinuous person." In The ethical condition: Essays on action, person \& value, 302-28. Chicago: University of Chicago Press.

- 2015c. "Both/And." In What is existential anthropology?, edited by Michael Jackson and Albert Piette, 58-83. Oxford: Berghahn.

Latour, Bruno. 1996. Petite réflexion sur le culte moderne des Dieux faitiches. Le Plessis Robinson: Synthélabo Groupe.

2002. Jubiler ou les tourments de la parole religieuse. Paris: La Découverte.

Lévi-Strauss, Claude. 1963. Structural anthropology. Volume 1. New York: Doubleday. 
Lévy-Bruhl, Lucien. 1910. Les fonctions mentales dans les sociétés inférieures. Paris: Alcan.

Lohmann, Roger. 2009. “Dreams of fortune: Reo Fortune’s psychological theory of cultural ambivalence." Pacific Studies 32 (2-3): 273-98.

Luhrmann, Tanya. 1991. Persuasions of the witch's craft: Ritual magic in contemporary England. Cambridge: Harvard University Press.

Mair, Jonathan. 2015. "The discourse of ignorance and the ethics of detachment among Mongolian Tibetan Buddhists in Inner Mongolia, China." In Detachment: Essays on the limits of relational thinking, edited by Matei Candea, Joanna Cook, Catherine Trundle, and Thomas Yarrow, 236-55. Manchester: Manchester University Press.

Mannoni, Octave. 1969. Clefs pour l'imaginaire ou l'autre scène. Paris: Editions du Seuil.

McCabe, Donald. 1992. "The influence of situational ethics on cheating among college students." Sociological Inquiry 62 (3): 365-74.

McDonough, Conor. 2011. "Grounding speech and silence: Cataphaticism and apophaticism in Denys and Aquinas," Irish Theological Quarterly 76 (1): 57-76.

Mithen, Steven. 1996. The prehistory of the mind. London: Thames and Hudson.

Nietzsche, Friedrich. (1896) 1966. Beyond good and evil. New York: Vintage Books.

Noudelmann, François. 2015. Le génie du mensonge. Paris: Max Milo Editions.

Ogien, Ruwen. 2011. L'influence de l'odeur des croissants chauds sur la bonté humaine et autres questions de philosophie morale expérimentale. Paris: Grasset.

Piette, Albert. 2013. Lorigine de la croyance. Paris: Berg International.

_ 2015a. Existence in the details: Theory and methodology in existential anthropology. Berlin: Duncker \& Humblot.

_. 2015b. "Existence, minimality and believing." In What is existential anthropology?, edited by Michael Jackson and Albert Piette, 178-213. New York-Oxford: Berghahn Books.

Provencher, Claudine. 2011. "Towards a better understanding of cognitive polyphasia." Journal for the Theory of Social Behaviour 41 (4): 377-95.

Public Policy Advisory Network on Female Genital Surgeries in Africa. 2012. Seven things to know about female genital surgeries in Africa. The Hasting Center Report 42: 19-27. http://www.thehastingscenter.org/Publications/HCR/Detail.aspx?id=6059.

Rappaport, Roy. 1999. Ritual and religion in the making of humanity. Cambridge: Cambridge University Press.

Roubiczek, Paul. 1952. Thinking in opposites, an investigation of the nature of man as revealed by the nature of thinking. London: Routledge and Kegan Paul.

Searle, John. 1983. Intentionality: An essay in the philosophy of mind. Cambridge: Cambridge University Press.

Scheper-Hughes, Nancy. 1995. "The primacy of the ethical: Propositions for a militant anthropology." Current Anthropology 36 (3): 409-20.

Schielke, Samuli and Liza Debevec. 2012. Ordinary lives and grand schemes: An anthropology of everyday religion. Oxford and New York: Berghahn Books. 
Schweitzer, Albert. 1925. The mystery of the kingdom of God: the secret of Jesus' Messiahship and passion. Translated by Walter Lowrie. London: A. and C. Black.

Shweder, R. A. 2013. “The goose and the gander: The genital wars." Global Discourse: An Interdisciplinary Journal of Current Affairs and Applied Contemporary Thought 3 (2): 348-66.

Tambiah, Stanley. 1990. Magic, science, and the scope of rationality. Cambridge and New York: Cambridge University Press.

Trouche, Emmanuel, Petter Johansson, Lars Hall, and Hugo Mercier. 2015. “The selective laziness of reasoning." Cognitive Science: 1-15. doi: 10.1111/cogs.12303.

Turner, Denys. 1995. The darkness of God: Negativity in Christian mysticism. Cambridge: Cambridge University Press.

Turner, Victor. 1969. The ritual process: Structure and anti-structure. Chicago: Aldine.

Vermersch, Pierre. 1999. "Introspection as practice." Journal of Consciousness Studies 6 (2-3): 17-42.

Veyne, Paul. 1983. Les Grecs ont-ils cru à leurs mythes? Paris: Seuil.

Wilk, Richard. 2001. “Consuming morality.” Journal of Consumer Culture 1 (2): 269-84.

Zigon, Jarrett. 2007. "Moral breakdown and the ethical demand. A theoretical framework for an anthropology of moralities." Anthropological Theory 7 (2): 131-50.

\section{L'anthropologie et létude des contradictions}

Résumé : S’il est bien un aspect fondamental de la vie humaine, ce sont les contradictions. Les humains sont pétris de pensées, de sentiments et d'attitudes contradictoires. En anthropologie, il existe une littérature abondante sur les contradictions culturelles entre groupes ainsi que sur les contradictions au sens marxiste du terme. Dans ce débat, cinq anthropologues adoptent un point de vue individualiste et phénoménologique sur ce phénomène. Comment peut-on vivre avec ses contradictions? Comment les décrire d'un point de vue anthropologique? Surtout, devrionsnous repenser notre chère notion d'acteur social à travers celle de contradiction?

David Berliner

Laboratoire d'Anthropologie des Mondes Contemporains

Université Libre de Bruxelles

CP 124, 44 avenue Jeanne

1050 Brussels

Belgium

David.Berliner@ulb.ac.be

Michael Lambek

Department of Anthropology University of Toronto, Scarborough 1265 Military Trail, ON. M1C 1A4

Canada

lambek@utsc.utoronto.ca 
Richard Shweder Department of Comparative Human Development The University of Chicago 1126 East 59th Street Chicago, IL 60637 USA rshd@uchicago.edu

Richard Irvine Division of Social Anthropology University of Cambridge Free School Lane Cambridge CB2 3RF

$$
U K
$$
rdgi2@cam.ac.uk

Albert Piette Université de Paris-Ouest (Nanterre) 200, avenue de la République 92001-Nanterre Cedex France piettealbert@hotmail.com 